\title{
FUNGSI LEMBAGA PEMASYARAKATAN DALAM MELAKSANAKAN PEMBINAAN TERHADAP WARGA BINAAN PEMASYARAKATAN (WBP) (Di Lembaga Pemasyarakatan Perempuan Kelas IIA Denpasar)
}

\author{
I Wayan Kevin Mahatya Pratama, A. A. Sagung Laksmi Dewi, I Made Minggu Widyantara \\ Fakultas Hukum, Universitas Warmadewa, Denpasar-Bali, Indonesia \\ kevinmahatya9@gmail.com, mademinggu21@gmail.com, laksmiidewi29@gmail.com
}

\begin{abstract}
Abstrak
Pemasyarakatan dalam sistemnya berguna untuk mempersiapkan orang terpidana di Lapas dapat menyatu dengan normal dan diterima di masyarakat kembali. Menyatu dengan normal lagi artinya memulihkan hubungan diantara Terpidana atau sering disebut juga WBP bersama masyarakat. Lembaga Pemasyarakatan merupakan tempat Warga Binaan Pemasyarakatan (WBP) menjalani masa hukumannya. Penelitian ini bertujuan untuk mengetahui fungsi Lapas dalam melaksanakan pembinaan terhadap Warga Binaan Pemasyarakatan (WBP) dan menganalisis bentuk serta manfaat program pembinaan terhadap Warga Binaan Pemasyarakatan (WBP) yang diselenggarakan di Lembaga Pemasyarakatan Perempuan kelas II A Denpasar. Penelitian ini menggunakan metode penelitian hukum normative. Data-data yang diperoleh melalui pengamatan langsung di lapangan. Hasil penelitian menunjukan bahwa dalam Program Pembinaan dari Lembaga Pemasyarakatan khususnya lokasi penelitian ini diadakan yaitu di Lembaga Pemasyarakatan Perempuan Kelas IIA Denpasar sudah bekerjasama dengan instansi pemerintah, yayasan swasta, maupun organisasi kemasyarakatan yang bergerak dibidang wanita dalam melakukan pembinaan sekaligus juga mempromosikan hasil karya Narapidana atau Warga Binaan Pemasyarakatan (WBP) tersebut. Selain itu juga Lembaga Pemasyarakatan Perempuan Kelas IIA Denpasar menggelar dan mengikuti beberapa event pameran hasil karya Warga Binaan Pemasyarakatan (WBP). Kegiatan ini bertujuan untuk memperkenalkan hasil karya Warga Binaan Pemasyarakatan (WBP) kepada masyarakat dan memperjelas bahwa Lembaga Pemasyarakatan itu membimbing maupun membina Narapidana atau Warga Binaan Pemasyarakatan (WBP) untuk bisa berkarya dan dapat berkontribusi untuk masyarakat ketika mereka selesai menjalani masa hukumannya
\end{abstract}

Kata kunci: Pembinaan, Lembaga Pemasyarakatan, Warga Binaan Pemasyarakatan (WBP)

\begin{abstract}
Correctional in its system is useful for preparing convicted people in prisons to integrate normally and be accepted in society again. Merging normally again means restoring the relationship between the convicted or often referred to as Correctional Assistance and the community. The Penitentiary is a place for the Community Assisted to serve their sentence. This study aims to determine the function of prisons in carrying out coaching for Correctional Assistance and to analyze the form and benefits of the guidance program for Correctional Assistance held at Class II A Denpasar Women's Penitentiary. This research uses normative legal research methods. The data obtained through direct observation in the field. The results showed that in the Guidance Program of the Correctional Institution, especially the location of this research, was held, namely the Class IIA Denpasar Women's Penitentiary, which has collaborated with government agencies, private foundations, and community organizations engaged in the field of women in providing guidance as well as promoting the work of prisoners or residents. Correctional Assistance (WBP). In addition, the Class IIA Denpasar Women's Penitentiary held and participated in several exhibitions of the work of the Community Assisted Citizens (WBP). This activity aims to introduce the work of the Community Assisted Citizens (WBP) to the community and make it clear that the Correctional Institution guides or fosters Prisoners or Prisoners (WBP) to be able to work and be able to contribute to society when they finish serving their sentence.
\end{abstract}

Keywords: Guidance, Penitentiary, Correctional Assistance

\section{PENDAHULUAN}

Sistem pemasyarakatan dilakukan sebagai upaya mengarahkan terpidana atau Warga Binaan Permasyarakatan (WBP) yang nantinya diharapkan menjadi manusia yang bisa menyadarinya dari perbuatan yang salah di masa lampau. Sehingga, diharapkan pantang mengulangi perbuatan yang menimbulkan akibat pidana yang sama ketika mereka bebas, bisa menjadi karakter yang ikut serta 
dalam pembangunan bangsa, dan bisa hidup normal kembali di masyarakat (Rivai, 2014). Menjadi pribadi yang normal kembali artinya adalah upaya untuk mengembalikan seperti semula hubungan warga binaan pemasyarakatan dengan pribadinya, manusia dengan sesamanya, dan manusia dengan lingkungannya. Fungsi dari Sistem Pemasyarakatan mempersiapkan WBP bisa berinteraksi normal Kembali dengan masyarakat, yang nantinya dapat menjadi karakter yang diterima kembali di dalam masyarakat dan menjadi pribadi yang menghindari tindak kejahatan. Berinteraksi dan membaur kembali artinya memulihkan hubungan di antara WBP dengan masyarakat ketika sudah bebas dan kembali menghirup udara bebas (Harsono, 1995).

Lapas adalah tempat untuk membina warga binaan pemasyarakatan (WBP) yang mempunyai banyak program pembinaan yang sangat bermanfaat untuk warga binaan pemasyarakatan (WBP) ketika nanti mereka sudah selesai menjalani masa pidana/hukumannya.Program pembinaan terhadap Warga Binaan Pemasyarakatan meliputi pembinaan intramural (di dalam lapas) dan pembinaan ekstramural (Di luar lapas). Program pembinaan terdiri dari 2 program yaitu program pembinaan kepribadian dan program pembinaan kemandirian. Program pembinaan kepribadian berupa bimbingan yang tertuju pada mental dan watak warga binaan pemasyarakatan (WBP) agar menjadi seseorang yang mempunyai karakter yang berguna, bertaqwa kepada Tuhan Yang Maha Esa, dan bertangung jawab kepada diri sendiri, keluarga dan masyarakat. Program pembinaan kemandirian bertujuan untuk mengarahkan dan mengasah bakat dan keterampilan Warga Binaan Pemasyarakatan (WBP).

Namun, dalam kenyataannya masyarakat tidak mengetahui mengenai program pembinaan yang dilakukan di Lapas Terhadap Warga Binaan Pemasyarakatan atau Narapidana sehingga ketika mereka telah selesai menjalani masa hukumannya mantan narapidana sering mendapat perlakukan diskriminatif dan tidak mendapatkan pembinaan yang baik di Lapas. Hal ini berimbas pada Lapas yang masih dianggap sebagai sarang kriminal atau tempat belajar kejahatan.

Berikut ini beberapa penelitian serupa, yaitu penelitian yang mengkaji rumusan yang serupa tetapi dengan hasil yang berbeda salah satunya mengenai fungsi sistem pemasyarakatan dalam merehabilitasi dan mereintegrasi social warga binaan pemasyarakatan (Wulandari, 2015), selanjutnya mengenai peran lembaga pemasyarakatan dalam membina narapidana penyalahgunaan narkotika menurut UU Nomor 12 Tahun 1995 ditinjau dari FIQH Siyasah (Riyan, 2019), dan peranan Lembaga pemasyarakatan dalam pembinaan keterampilan bagi narapidana kasus di lembara pemasyarakatan Purwokerto (Hidayat, 2011).

Berdasarkan uraian singkat tersebut maka dapat ditarik permasalahan yaitu bagaimanakah fungsi Lapas dalam melakukan pembinaan terhadap Warga Binaan Pemasyarakatan (WBP) serta bagaimanakah bentuk dan manfaat program pembinaan terhadap Warga Binaan Pemasyarakatan (WBP) yang diselenggarakan di Lembaga Pemasyarakatan Perempuan kelas II A Denpasar.

\section{METODE PENELITIAN}

Jenis penelitian ini menggunakan hukum normatif, yaitu jenis penelitian yang menilai suatu peraturan perundang-undangan dan dilakukan dengan mengadakan penelitian kepustakaan (Fajar \& dkk, 2010), dengan metode pendekatan Statute Approach (Pendekatan Perundang- undangan), Conceptual Approach (Pendekatan Konseptual) dan Case Approach (pendekatan Kasus) (Marzuki, 2010). Sumber Hukum dari penelitian tersebut yaitu bahan hukum primer meliputi Bahan hukum primer yaitu bahanbahan hukum berupa peraturan Perundang-undangan. Bahan Hukum Sekunder yaitu bahan-bahan hukum berupa buku, hasil penelitian, artikel ilmiah, dan jurnal pada website mengenai ilmu hukum maupun tentang pemasyarakatan. Data didukung dengan keterangan narasumber dari tempat dilakukannya penelitian mengenai isu hukum yang dibahas.

\section{HASIL DAN PEMBAHASAN}

\section{Fungsi Lembaga Pemasyarakatan dalam Melakukan Pembinaan terhadap Warga Binaan Pemasyarakatan (WBP)}

Konsep awal yang menjadikan awal dari fungsi Lembaga Pemasyarakatan itu sendiri adalah Sistem Pemasyarakatan. Sistem Pemasyarakatan bisa menjadikan terwujudnya citra tersebut, dan memperlakukan narapidana menjadi subject. Disinilah sisi kemanusiaan itu ada, keberadaan manusia lebih diperlihatkan, memperlihatkan kesejajaran dan kesetaraan sama seperti manusia lainnya. pengarahan dan perlakuan yang keras di kendorkan dan terpidana diberi pembinaan, agar kelak setelah 
habis masa tahanan dari Lapas sudah bersikap baik,sopan, dan bahkan dapat memberikan contoh positif di lingkungannya setelah mengalami bimbingan dari dalam Lembaga Pemasyarakatan (Harsono, 1995).

Lembaga pelaksana pidana penjara di Indonesia adalah Lapas dengan memberlakukan sistem pemasyarakatan. Sistem pemasyarakatan memegang peranan di dalam membangun sistem hukum pidana bidang di dalam pelaksanaannya di Indonesia (Priyatno, 2013). Lapas atau Lembaga Pemasyarakatan merupakan tempat untuk melakukan pembinaan terhadap narapidana atau WBP.

Lapas merupakan tempat untuk membina narapidana yang berlandaskan sistem yaitu sistem pemasyarakatan yang berusaha untuk mencapai pemidanaan yang berintegrasi dengan kata lain melakukan pembinaan dan memulihkan kesatuan yang berguna dan baik di masyarakat. Jadi istilah lainnya Lapas melakukan rehabilitation, reeducation and resocialization, serta memberikan narapidana serta masyarakat perlindungan pada saat pelaksanaan sistem pemasyarakatan. Pola dasar pembinaan narapidana di Lapas diharapkan dapat berhasil dalam mencapai resosialisasi dan rehabilitasi pelaku tindak pidana/narapidana melalui sistem pemasyarakatan, yang nantinya diharapkan akan menekan laju tindak kejahatan dan mencapai kesejahteraan sosial seperti tujuan dari sistem peradilan pidana baik itu dalam jangka pendek, jangka menengah maupun jangka panjang. Jadi, pada intinya keberhasilan sistem peradilan pidana ditentukan dengan keberhasilan sistem pemasyarakatan dalam pelaksanaan pembinaan pada Lapas (Surianto, 2018). Ada empat tahapan proses melaksanakan pembinaan tersebut:

a. Tahapan pertama. Dilakukan penelitian terhadap narapidana/WBP yang baru memasuki Lapas mengenai keterangan-keterangan diri mereka sekaligus penyebab mereka melakukan pelanggaran atau tindak pidana.

b. Tahapan kedua. Ketika proses pembinaan bagi narapidana/WBP berjalan selama 1/3 (sepertiga) dari masa hukuman pidana sebenarnya, serta menurut penilaian dari Dewan Pembina Pemasyarakatan telah dilihat ada perbaikan pada diri narapidana/WBP, diantaranya sudah menunjukan perilaku disiplin,patuh dengan aturan tata tertib di lembaga pemasyarakatan serta menunjukan perilaku sadar akan kesalahannya, maka narapidana tersebut diberlakukan pengawasan tingkat medium security.

c. Tahapan ketiga. Ketika proses pembinaan berjalan selama $1 / 2$ (setengah) dari masa hukuman pidana sebenarnya, dan berdasarkan penilaian Dewan Pembina Pemasyarakatan telah dilihat ada kemajuan dari sisi fisik,mental dan keterampilan narapidana/WBP, maka ruang lingkup pembinaan diperluas dengan diperbolehkan untuk menjalankan asimilasi dengan masyarakat di luar lembaga pemasyarakatan bagi narapidana/WBP yang bersangkutan.

d. Tahap keempat. Ketika proses pembinaan sudah berjalan selama 2/3 (dua per tiga) dari masa hukuman pidana sebenarnya atau sekurang-kurangnya 9 (sembilan) bulan, kepada narapida/WBP sudah dapat memperoleh lepas bersyarat, yang pengusulan lepas bersayarat tersebut ditentukan oleh Dewan Pembina Pemasyarakatan (Surianto, 2018).

Pembinaan di Lembaga Pemasyarakatan terdiri dari 2 Jenis yaitu Pembinaan Kepribadian dan Kemandirian. Pembinaan kepribadian diatur di dalam Keputusan Menteri Kehakiman RI. Dalam pelaksanaan pembinaan tentu ada pembagian jenis pembinaan tersebut yaitu:

1. Pembinaan Kesadaran Beragama

Dalam Pembinaan jenis ini narapidana/WBP akan dibina untuk lebih bertaqwa kepada Tuhan Yang Maha Esa, menyadari segala dosa dan kesalahannya yang menyebabkan mereka berada di Lapas, serta dapat mengamalkan ilmu agamanya di masyarakat nanti dan agar tidak mengulangi tindak kejahatannya lagu.

2. Pembinaan Kesadaran Intelektual

Dalam pembinaan intelektual ditekankan untuk membina dari segi pengetahuan dari narapidana/WBP tersebut sehingga nantinya mereka tidak tertinggal dari segi pengetahuan maupun wawasan. Hal ini bisa diimplementasikan dengan cara penyediaan perpustakaan untuk narapidana selain itu narapidana juga dapat mendapat informasi dari televisi yang ada.

3. Pembinaan Kesadaran Hukum

Pembinaan kesadaran hukum dimaksudkan agar narapidana/WBP mengetahui mengenai apa itu hukum, sistem hukum, serta mekanisme hukum di Indonesia tentunya sehingga mereka akan tahu perbuatan apa yang dilarang oleh hukum dan juga dapat mengetahui hak dan kewajiban mereka selama menjadi narapidana/WBP.

4. Pembinaan Pengintegrasian dengan Masyarakat 
Pembinaan ini dilaksanakan untuk memudahkan narapidana untuk berintegrasi dengan masyarakat diharapkan nantinya narapidana akan lebih mudah bersosialisasi dengan masyarakat saat masa pidananya berakhir.

Pembinaan Kemandirian merupakan program pembinaan yang dilakukan untuk menunjang soft skill atau keterampilan kerja dari Narapidana yang dilakukan oleh Lapas dengan melibatkan pihak ketiga yaitu dari lembaga pemerintah, Lembaga/Perusahaan Swasta dalam menunjang proses pembinaannya. Hak narapidana atau Warga Binaan Pemasyarakatan sekaligus merupakan bagian dari program pembinaan di Lembaga Pemasyarakatan adalah Remisi, Asimilasi, Pembebasan Bersyarat, Cuti Menjelang Bebas, Cuti Mengunjungi Keluarga dan Cuti Bersyarat.

\section{Bentuk dan Manfaat Program Pembinaan Terhadap Warga Binaan Pemasyarakatan (WBP) yang Diselenggarakan di Lembaga Pemasyarakatan Perempuan kelas II A Denpasar}

Mengenai bentuk dan manfaat program pembinaan Warga Binaan Pemasyarakatan (WBP), peneliti memilih lokasi penelitian di Lembaga Pemasyarakatan Perempuan Kelas IIA Denpasar yang beralamat di Jl. Intan Permai, Kerobokan Kelod, Kec. Kuta Utara, Kabupaten Badung, Bali. Pembinaan Narapidana di Lembaga Pemasyarakatan Perempuan Kelas IIA Denpasar dilaksankaan dalam bentuk pembinaan kepribadian dan pembinaan kemandirian.

Pembinaan kepribadian yang ada di Lembaga Pemasyarakatan Perempuan Kelas IIA Denpasar ada beberapa program pembinaan. Dalam wawancara dengan Ibu Ni Ketut Sukiati yang menjabat sebagai Kepala Seksi Pembinaan Narapidana dan Anak Didik beserta Ibu Ni Putu Eka Rachmawati yang menjabat sebagai Kepala Sub Seksi Bimbingan Kemasyarakatan dan Perawatan Narapidana pada tanggal 29 juli 2019 beserta data-data tertulis yang penulis minta dari beliau berdua. Ada beberapa program yang memang sudah berjalan di Lapas Perempuan Kelas IIA Denpasar yaitu:

1. Mapenaling

Mapenaling atau masa pengenalan lingkungan adalah tahapan pertama ketika narapidana/WBP baru memasuki Lapas untuk menjalani masa hukumannya. Pada masa Mapenaling narapidana akan mendapatkan arahan terkait aturan di Lembaga Pemasyarakatan (LAPAS) dan kewajibankewajiban sebagai tahanan. Mapenaling bermanfaat agar narapidana atau Warga Binaan Pemasyarakatan (WBP) bisa menyesuaikan dirinya dengan lingkungan Lapas.

2. Pembinaan Mental dan Kesadaran Keagamaan

Pembinaan ini bermanfat meningkatkan keimanan dan ketaqwaan kepada Tuhan Yang Maha Esa, yang nantinya Narapidana/WBP sadar akan kesalahannya dan mau bertobat. Di Lembaga Pemasyarakatan Perempuan Kelas IIA Denpasar dilakukan pembinaan yaitu kegiatan peribadatan dan ceramah oleh penceramah dari tokoh agama sesuai dengan agama yang dianut masing-masing narapidana/WBP seperti agama Islam, Hindu, Katholik, Kristen dan Budha. Pembinaan tersebut dilaksanakan setiap hari senin, kamis, dan sabtu. Dalam menjalankan kegiatan pembinaan mental/kerohanian tersebut bekerjasama dengan kementerian Agama. Kerjasama ini sudah diadakan penandatanganan MOU antara Pihak Lembaga Pemasyarakatan Perempuan Kelas IIA Denpasar dengan Kantor Kementerian Agama Kota Denpasar terkait kerjasama antara kedua Institusi.

3. Pembinaan Jasmani

Pembinaan dimaksudkan untuk memberikan narapidana/WBP suatu kegiatan untuk membina jasmani mereka sehingga tubuh mereka menjadi sehat dan bugar dan diharapkan terhindar dari penyakit. Kegiatan yang dilaksanakan antara lain: senam pagi, bulu tangkis. Berdasarkan hasil pengamatan penulis yang dilakukan di tempat penelitian yaitu Lembaga Pemasyarakatan Perempuan Kelas IIA Denpasar, pembinaan jasmani atau olahraga dilakukan setiap hari senin sampai dengan hari jumat. Pelaksanaan olahraga senam pagi mulai pukul 07.30 WITA sampai dengan 08.30 WITA dan setelah itu narapidana/ WBP biasanya memainkan jenis olahraga lain, seperti olahraga Bulu Tangkis. Kegiatan ini diikuti oleh semua Narapidana. dan terkadang Olahraga ini juga diikuti oleh petugas Lapas sebagai bentuk harmonisasi antara petugas dan narapidana/WBP dan merupakan bagian dari pembinaan narapidana/WBP instruktur yang untuk kegiatan senam terkadang ada sukarelawan yang mau mengajari narapidana/WBP sehingga untuk selanjutnya mereka bisa melakukan gerakan senam sendiri atau dari salah satu narapidana/WBP yang sudah memang mahir melakukan gerakan senam sebelum mereka masuk ke Lapas karena melakukan tindak pidana. 
4. Pembinaan Kesadaran berbangsa dan bernegara

Dalam melaksanakan pembinaan kesadaran berbangsa dan bernegara untuk saat ini Lembaga Pemasyarakatan Perempuan Kelas IIA Denpasar melaksanakan kegiatan apel Warga Binaan Pemasyarakatan (WBP) dengan berbaris rapi di halaman depan blok hunian. Pada saat petugas sudah selesai menghitung jumlah dari Warga Binaan Pemasyarakatan, dilanjutkan dengan pembacaan Catur Dharma Narapidana yang dibacakan perwakilan Narapidana/Warga Binaan Pemasyarakatan dan diikuti oleh semua Narapidana/Warga Binaan Pemasyarakatan. Untuk pelaksanaan apel tersebut dilakukan setiap hari tanpa melihat hari libur (Hasan \& dkk, 2019). Namun pada saat apel siang dan malam biasanya dilaksanakan melalui apel dalam Blok hunian dan tidak berbaris di lapangan.

Setiap tanggal 17 Agustus biasanya diadakan lomba-lomba untuk Warga Binaan Pemasyarakatan (WBP) dalam rangka memperingati hari kemerdekaan Indonesia ,Pada tanggal 17 agustus 2019 diadakan lomba-lomba diantaranya lomba makan kerupuk,lari kelereng,membaca puisi tema kemerdekaan, lomba paduan suara antara blok hunian warga binaan pemasyarakatan (WBP). Manfaat dari program pembinaan ini adalah Warga Binaan Pemasyarakatan dapat menanamkan kesadaran berbangsa dan bernegara, mencintai tanah air, sehingga nantinya tidak mengulangi perbuatan melanggar hukum yang bertentangan dengan aturan negara.

5. Pembinaan Kemampuan Intelektual (Kecerdasan)

Dalam pembinaan kemampuan intelektual merupakan salah satu pembinaan yang dilakukan di Lapas Perempuan Kelas IIA Denpasar. Dalam program pembinaan tersebut Lapas Perempuan Kelas IIA Denpasar bekerjasama dengan Dinas Arsip dan Kepustakaan Kabupaten Badung untuk menyediakan Perpustakaan Lapas. Kerjasama yang dilakukan meliputi penyediaan lemari dan buku-buku bacaan dengan status bahwa Lembaga Pemasyarakatan Perempuan Kelas IIA Denpasar meminjam lemari beserta buku-buku bacaan dari Dinas Arsip dan Kepustakaan Kabupaten Badung.

Lembaga Pemasyarakatan Perempuan Kelas IIA Denpasar juga bekerja sama dengan pihak yayasan swasta dalam pembinaan pendidikan kemampuan intelektual dengan Yayasan Pertiwi melalui surat perjanjian Kerjasama Lembaga Pemasyarakatan Perempuan Kelas IIA Denpasar Nomor: W20.PK.01.08.03-174 Tahun 2020 dan Yayasan Pertiwi Nomor: 001/PertiwiSPK/II/2020. Ruang lingkup perjanjian kerjasama meliputi pembinaan bidang pendidikan dalam bentuk kelas perempuan sadar hukum dan kelas parenting bagi Narapidana/WBP. Pelaksanaan kegiatan tersebut bermanfaat untuk Narapidana/WBP agar mereka membuka wawasan mengenai pentingnya kesadaran hukum dan parenting setelah mereka selesai menjalani masa hukumannya.

6. Pembinaan mengintegrasikan diri dengan masyarakat (re-integrasi sosial).

Dari data yang penulis peroleh pada Seksi Bimbingan Narapidana dan Anak Didik terdapat 43 Warga Binaan Pemasyarakatan yang sudah mendapat Pembebasan Bersyarat (PB) dalam kurun waktu dari bulan Januari 2019 sampai dengan Juni 2020,37 Warga Binaan Pemasyarakatan yang sudah mendapat Cuti Bersyarat (CB) dalam kurun waktu dari bulan Januari 2019 sampai dengan Juni 2020,1 Warga Binaan Pemasyarakatan yang sudah mendapat Cuti Menjelang Bebas (CMB) dalam kurun waktu dari bulan Januari 2019 sampai dengan Juni 2020,18 Narapidana atau Warga Binaan Pemasyarakatan (WBP) yang mendapatkan Asimilasi data dari tanggal 31 Maret sampai dengan 28 April 2020. Berdasarkan Surat Edaran Nomor: PAS516.PK.01.04.06 Tahun 2020 sebagai upaya pencegahan dan penanggulangan covid-19.

Lapas Perempuan Kelas IIA Denpasar menyelenggarakan program kegiatan yaitu Bimbingan Kerja (BIMKER). Kegiatan pembinaan ini dimaksudkan memberi soft skill kepada Narapidana/WBP sehingga bisa menunjang kehidupannya sebagai mata pencaharian ketika mereka selesai menjalani masa hukumannya. Menurut data yang penulis dapatkan dari Ibu Made Marhena Pucangan yang menjabat sebagai Kepala Seksi Kegiatan Kerja serta Ibu Ida Ayu Agung Kartini Kepala Sub seksi Bimbingan Kerja dan Pengelolaan Hasil Kerja baik dari data tertulis dan wawancara langsung pada tanggal 29 Juli 2020, program pembinaan ini yang diselenggarakan oleh Lapas Perempuan Kelas IIA Denpasar bekerja sama dengan Balai Latihan Kerja Industri dan Pariwisata yang meliputi bidang tata rias, SPA, menjahit dan Food Processing. 
Kerjasama ini dituangkan dalam bentuk Perjanjian Kerjasama (Nota Kesepakatan) Nomor: W20.pk.01.06.03/2020, Nomor 424/67 /VI/UPTD/ BLK .IP/ Disnaker ESDM Tentang Kerjasama Bidang Tenaga Pelatih/Instruktur. Selain Dari Balai Latihan Kerja Industri dan Pariwisata, Lembaga Pemasyarakatan Perempuan Kelas II A Denpasar juga melakukan kerjasama dari pihak swasta untuk terus menambah kegiatan pembinaan kemandirian yang menunjang skill Warga Binaan Pemasyarakatan ketika mereka selesai menjalani hukumannya. Yayasan Tangan Kasih Indonesia beserta Air AID Inc. (Yayasan Luar Negeri yang berasal dari Australia) bekerjasama dengan Lembaga Pemasyarakatan Perempuan Kelas IIA melalui MoU (Memorandum of Understanding) atau Surat Perjanjian Kerjasama di bidang pembinaan Haircut training (pelatihan potong rambut). Selain itu, terdapat juga kegiatan pembinaan kemandirian yaitu merajut, melukis dan makrame yang instruktur atau pengajarnya berasal dari tenaga sukarelawan melalui ijin dari Kalapas dengan bersurat terlebih dahulu.

\section{SIMPULAN DAN SARAN}

\section{Simpulan}

Dalam Program Pembinaan dari Lembaga Pemasyarakatan khususnya lokasi penelitian ini diadakan yaitu di Lembaga Pemasyarakatan Perempuan Kelas IIA Denpasar sudah bekerjasama dengan instansi pemerintah, yayasan swasta,maupun organisasi kemasyarakatan yang bergerak dibidang wanita dalam melakukan pembinaan sekaligus juga mempromosikan hasil karya Narapidana atau Warga Binaan Pemasyarakatan (WBP) tersebut. Selain itu juga Lembaga Pemasyarakatan Perempuan Kelas IIA Denpasar menggelar dan mengikuti beberapa event pameran hasil karya Warga Binaan Pemasyarakatan (WBP). Kegiatan ini bertujuan untuk memperkenalkan hasil karya Warga Binaan Pemasyarakatan (WBP) kepada masyarakat dan memperjelas bahwa Lembaga Pemasyarakatan itu membimbing maupun membina Narapidana atau Warga Binaan Pemasyarakatan (WBP) untuk bisa berkarya dan dapat berkontribusi untuk masyarakat ketika mereka selesai menjalani masa hukumannya.

\section{Saran}

Melalui penelitian ini diharapakan kepada Direktorat Jenderal Pemasyarakatan agar terus membenahi proses dan program pembinaan Warga Binaan Pemasyarakatan (WBP) sesuai perkembangan zaman sehingga nantinya Warga Binaan Pemasyarakatan (WBP) dapat memberikan kontribusi di dalam masyarakat maupun dapat menafkahi dirinya sendiri ketika nanti selesai menjalani hukuman. Untuk Masyarakat agar lebih memahami lagi konsep yang dilakukan oleh Lembaga Pemasyarakatan dalam membina narapidana/WBP, yang nantinya diharapkan agar mindset negatif terkait Lembaga Pemasyarakatan dapat dihilangkan karena sebenarnya Lembaga Pemasyarakatan melakukan pembinaan terhadap Warga Binaan Pemasyarakatan (WBP) agar bisa berinteraksi kembali dalam lingkungan masyarakat bahkan dapat berkontribusi dalam masyarakat. Selain itu, peran masyarakat sangat dibutuhkan dalam kesuksesan program pembinaan ini ketika nanti Warga Binaan Pemasyarakatan (WBP) telah selesai menjalani hukumannya. Berikan motivasi agar mereka dapat berbuat baik dan dapat berkontribusi di dalam masyarakat.

\section{DAFTAR PUSTAKA}

Fajar, M., \& Dkk. (2010). Dualisme Penelitian Hukum Normatif dan Empiris. Yogyakarta: Pustaka Belajar. Harsono. (1995). Sistem Baru Pembinaan Narapidana (I). Jakarta: Djambatan.

Hasan, I. L., \& Dkk. (2019). Hari-Hari di Sukamiskin (I). Solo: PT. Era Adicitra Intermedia.

Hidayat, T. (2011). Peranan Lembaga Pemasyarakatan dalam Pembinaan Ketrampilan Bagi Narapidana Kasus di Lembaga Pemasyarakatan Purwokerto (Universitas Negeri Semarang).

Marzuki, P. M. (2010). Penelitian Hukum (VI). Jakarta: Predana Media Group.

Priyatno, D. (2013). Sistem Pelaksanaan Pidana Penjara di Indonesia (I). Bandung: Refika Aditama.

Rivai, A. W. (2014). Buku Pintar Pemasyarakat. Jakarta: Lembaga Kajian Pemasyarakatan.

Riyan. (2019). Peran Lembaga Pemasyarakatan dalam Membina Narapidana Penyalahgunaan Narkotika Menurut UU Nomor 12 Tahun 1995 Ditinjau Dari Fiqh Siyasah (Studi Pada Lembaga Pemasyarakatan Kelas 1 Bandar Lampung) Proposal (Universitas Islam Negeri Raden Intan Lampung).

Surianto. (2018). Menata Sumber Daya Warga Binaan Pemasyarakatan (Modal Manusia yang Tersembunyi di Rutan) (I). Makassar: CV Sah Media.

Wulandari, S. (2015). Fungsi Sistem Pemasyarakatan dalam Merehabilitasi dan Mereintegrasi Sosial Warga Binaan Pemasyarakatan. Serat Acitya-Jurnal Ilmiah, 2(2), 91. 